\title{
Direct and correlated responses from selection for early sexual maturity in Japanese quail
}

\author{
Aboul-Hassan M. A., Aboul-Seoud D. I., Ramzy A. A." \\ Department of Animal Production, Faculty of Agriculture, Al-Azhar University, Cairo, Egypt
}

\begin{abstract}
Base population after third generation of selection conclude total number of 788 birds at 6 weeks of age were used in this study and randomly assigned to two mating groups. First groupe was selected for early age at sexual maturity (EASM) and the second was as a control line (RBC) to study the direct and correlated responses for this direct of selection. The results can be summarized as follow:

1. EASM was highly significantly $(\mathrm{P} \leq 0.01)$ decreased from 39.54 days to 35.23 days.

2. The actual and the expected selection differentials were 2.52 and $2.29 \mathrm{~g} /$ generation

3. The actual response to selection in the (EASM) line was $1.46 \mathrm{~g} /$ generation.

a- Heritability of EASM estimated ranged from 0.29 to 0.35

b- The realized heritability ranged from 0.44 to 0.79 .

c- Correlated responses for EASM were as follow:

d- $\mathrm{BW}_{0}, \mathrm{BW}_{2}, \mathrm{BW}_{4}$, and $\mathrm{BW}_{6}$ increased significantly $(\mathrm{P} \leq 0.05)$ from $9.95,40.58,98.84$ and $170.47 \mathrm{~g}$ to $10.47,47.01,101.87$ and $181.42 \mathrm{~g}$

e- Egg weight $(E W)$ was decreased $(\mathrm{P} \leq 0.05)$ from $10.74 \mathrm{~g}$ to $10.04 \mathrm{~g}$. But Body weight at sexual maturity (BWSM) was increased from $136.32 \mathrm{~g}$ to $139.32 \mathrm{~g}$. Total egg weight at first ten week $\left(\mathrm{TEN}_{10}\right)$ decreased from $55.25 \mathrm{eggs}$ to $54.25 \mathrm{egg}$.

f- Fertility (FR \%) was increased ( $\mathrm{P} \leq 0.05$ ) from $80.58 \%$ to $80.90 \%$. and Hatchability (HA \%) were increased $(\mathrm{P} \leq 0.05)$ from $70.42 \%$ to $70.92 \%$.

g- Meat, dressing and giblets \% were increased significantly ( $\mathrm{P} \leq 0.05)$ from 42.33, 62.04 and $14.27 \%$ to $43.76 \%, 63.99$ and $14.99 \%$.
\end{abstract}

Keywords: selection, early sexual maturity, direct response, correlated response, Japanese quail. 


\section{Introduction}

Selection experiments provide the framework for studying the inheritance of complex traits and allow the evaluation of theoretical predictions by testing observations against expectations. Depending on the time scale, short-term experiment can be used to estimate genetic variances and covariances to test their consistency from different sources of information and estimate the magnitude of the initial rates of response to selection (Varkoohi and Kaviani, 2014). The usefulness of selection procedures to increase either productive or reproductive traits depends not only upon the direct response itself, but also upon the associated changes in other economically or biologically important traits caused by correlated response to selection. However, selection for a certain trait may indirectly affect other traits not considered in the program due to the fact that the improved trait is correlated with these traits. Correlated responses were thourally discussed by Falconer (1954), Marks (1971) and Nestor et al. (1983). Japanese quail, despite their small body size, have an important place in commercial production because of their high egg and meat production capacity. They are generally reared for egg production in the Far East and Asian countries, and primarily for meat production in European and American countries (Minvielle, 2004). On The other hand, early sexual maturity promotes poultry production by increasing laying performance of the females and reducing the cost to produce males for semen Production. If there is a genetic correlation between characters under selection, the overall response to selection will change according to the heritability of the traits examined and the strength and sign of the genetic covariance among them (Jensen et al., 2003). The present work was designed to estimate the direct responses to selection for early sexual maturity and correlated responses with some productive and reproductive traits from generation zero to generation four of selection, as well as, to estimate the heritability of sexual maturity and to study the genetic and phenotypic correlations between early sexual maturity and each of growth, egg production, reproductive and carcass traits.

\section{Materials and methods}

Data of the present study were collected on the flock of Japanese quail (Coturnix japonica) maintained by the Department of Animal Production, Faculty of Agriculture, Al-Azhar University, Cairo, Egypt, during the period from May 2017 until September 2018.

\subsection{Breeding plan and management}

A total number of 788 birds (380 males and 408 females) at 6 weeks of age were taken at random from the flock under consideration as the parents of the present study. The mating system in the base population was in a ratio of one male to two females avoiding full and half-sib matings. The birds were randomly assigned to three mating groups; the first group were established by selection for early age at sexual maturity the second group was maintained as a randombred control line. Family selection was carried out within the selected line, however 
lower families in sexual maturity (one male and two females) were selected according to their deviation from the line mean. Feed and water were provided $a d-$ libitum. The experimental diet contained $28 \%$ protein and $2920 \mathrm{k}$ cal-ME/Kg until 2 weeks of age and $25 \%$ protein with $2850 \mathrm{k}$ cal-ME/Kg during 3-6 weeks of age, then changed to a ration contained $20 \%$ protein with $2820 \mathrm{k}$ cal-ME/Kg during the laying period. The minerals and vitamins were adequately supplied to cover the requirements according to $\mathrm{N} \mathrm{R}$ C, (1994). Temperature started with $37.5^{\circ} \mathrm{C}$ for the first week after hatching, then decreased $2-3^{\circ} \mathrm{C}$ weekly to $26-28^{\circ} \mathrm{C}$ at the fourth week of age till the end of brooding period. No vaccination and/or beak trimming programs were carried out to the breeding stocks.

\subsection{Statistical analysis}

Data of age at sexual maturity was analyzed by using Harvey's least-squares and maximum likelihood computer program (Harvey, 1987, model type 5) including each of line, generation, and sex as a fixed effects and sire and dam within sire as a random effect. The following model was adopted:

Yijmkln $=\mu+\mathrm{Gi}+\mathrm{Lj}+\mathrm{Sxm}+\mathrm{Sk}+\mathrm{Dlk}+$ eijmkln

Where, Yijmkln $=$ the observation of ijmkln th bird. $\mu=$ the overall mean, common element to all observations. $\mathrm{Gi}=$ the fixed effect of ith generation. $\mathrm{Lj}=$ the fixed effect of jth line. Sxm = the fixed effect of mth sex. $\mathrm{Sk}=$ the random effect of kth sire. Dlk = the random effect of lth dam nested within a random effect of kth sire. eijmkln $=$ the random error term. Henderson Method 3 (Henderson, 1953) was utilized to estimate the genetic variance components for the different traits studied.

\section{Results and Discussion}

\subsection{Direct response}

The actual means of early sexual maturity among four generations of selection in the selected and control lines are presented in (Table 1). Early age at sexual maturity (EASM) was highly significantly $(\mathrm{P} \leq 0.01)$ decreased in the selected line (EASM) from 39.54days at generation zero to 35.23days at the fourth generation of selection. On the other hand, age at sexual maturity in the control line fluctuated randomly from generation to another, as early sexual maturity decreased in the EASM line, the C.V\% of this trait increased from $38.04 \%$ at generation zero to $40.65 \%$ at the fourth generation, respectively (Table 1). The corresponding estimates obtained in the random bred control line (RBC) line were 38.04 and $43.03 \%$. The change in C.V\% from generation zero to generation four in EASM and RBC lines were significant $(\mathrm{P} \leq 0.01)$, the averages were $37.71 \%$ and $38.09 \%$ for EASM and RBD lines, respectively. These results agree with that of Abou Khadiga et al. (2016), Kaye et al. (2016) and Al-Tikriti, (2018), and not in agreement with those reported by Inal et al. (1996). 
Table (1): Actual means, standard deviations (S.D) and coefficients of variation (C.V \%) for early age at sexual maturity (d) in the selected and control lines among generations of selection.

\begin{tabular}{lcccc}
\hline $\begin{array}{l}\text { Line/ } \\
\text { Generation }\end{array}$ & $\begin{array}{c}\text { EASM } \\
\text { Mean } \pm \text { S.D }\end{array}$ & C.V\% & $\begin{array}{c}\text { RBC } \\
\text { Mean } \pm \text { S.D }\end{array}$ & C.V\% \\
\hline 0 & $39.54 \pm 15.04$ & 38.04 & $39.54 \pm 15.04$ & 38.04 \\
\hline 1 & $38.78 \pm 13.87$ & 35.77 & $38.62 \pm 13.92$ & 36.04 \\
\hline 2 & $36.90 \pm 13.61$ & 36.88 & $37.25 \pm 13.14$ & 35.28 \\
\hline 3 & $35.50 \pm 13.21$ & 37.21 & $36.14 \pm 13.76$ & 38.07 \\
\hline 4 & $35.23 \pm 14.32$ & 40.65 & $35.84 \pm 15.34$ & 43.03 \\
\hline Average & $37.19 \pm 13.51$ & 37.71 & $37.48 \pm 13.82$ & 38.09 \\
\hline EASM = Early age at sexual maturity, RBC = Random bred control line.
\end{tabular}

The least-square means, their standard errors and test of significance for factors affecting early sexual maturity are presented in tables (2 and 3). Results obtained in Table (2) indicated that among EASM line, age at sexual maturity decreased significantly $(\mathrm{P} \leq 0.05)$ from 37.08 days at the zero generation to 35.75 days at the fourth generation. On the other hand, the age at sexual maturity in the RBC line fluctuated randomly from generation to another; however there was no significant increase and/or decrease between the mean of the zero and the fourth generation of selection
(Table 2). The least-square means for factors affecting EASM varied significantly $\quad(\mathrm{P} \leq 0.05) \quad$ among generations, lines and sex, while the sire and the dam had non-significant effect on this trait (Table 3). The dam variance component in EASM were higher than the sire components of variance and consequently percentage of variations due to dam effect were larger than that of the sire effects obtained the non-genetic effects, primarily dominance and maternal, (40.88 and $27.73 \%$ vs 3.73 and $3.64 \%$ ), respectively as shown in (Table $4)$.

Table (2): Least-squares means and standard errors of early age at sexual maturity in the selected and control lines among generations of selection.

\begin{tabular}{lllll}
\hline \multirow{2}{*}{ Line/ Items } & \multicolumn{3}{c}{ EASM } & RBC \\
\cline { 2 - 5 } & No. & Means \pm S.E & No. & Means \pm S.E \\
\hline Generation: & & & \\
\hline $1^{\text {st }}$ & 168 & $37.08 \pm 0.28^{\mathrm{a}}$ & 120 & $38.08 \pm 0.32^{\mathrm{a}}$ \\
\hline $2^{\text {nd }}$ & 174 & $35.81 \pm 0.36^{\mathrm{b}}$ & 130 & $40.81 \pm 0.30^{\mathrm{a}}$ \\
\hline $3^{\text {rd }}$ & 195 & $34.92 \pm 0.26^{\mathrm{c}}$ & 125 & $39.65 \pm 0.26^{\mathrm{a}}$ \\
\hline $4^{\text {th }}$ & 175 & $35.75 \pm 0.16^{\mathrm{d}}$ & 114 & $41.12 \pm 0.38^{\mathrm{a}}$ \\
\hline Sex: & \multicolumn{5}{c}{} \\
\hline Male & 354 & $38.19 \pm 0.22^{\mathrm{a}}$ & 230 & $39.58 \pm 0.32^{\mathrm{a}}$ \\
\hline Female & 358 & $41.87 \pm 0.30^{\mathrm{b}}$ & 240 & $41.32 \pm 0.41^{\mathrm{b}}$ \\
\hline EASM = Early age at sexual maturity, RBC $=$ Random bred control line.
\end{tabular}


Table (3): F- ratios and test of significant for factors affecting early age at sexual maturity.

\begin{tabular}{lcc}
\hline S.O.V. & d.f & F-ratio \\
\hline Generation & 3 & $18.83^{\text {*** }}$ \\
\hline Sire & 226 & 1.79 \\
\hline Dam :(S) & 247 & 1.54 \\
\hline Line & 1 & $38.08^{* *}$ \\
\hline Sex & 1 & $25.87^{\text {*** }}$ \\
\hline Remainder & 1231 & \\
\hline
\end{tabular}

Table (4): Variance components $\left(\delta^{2}\right)$ and percentage of variation (V \%) estimated for random effects on early age at sexual maturity.

\begin{tabular}{lcccccc}
\hline \multirow{2}{*}{$\begin{array}{l}\text { Variance } \\
\text { components/ Line }\end{array}$} & \multicolumn{2}{c}{ Sire } & \multicolumn{2}{c}{ Dam: Sire } & \multicolumn{2}{c}{ Remainder } \\
\cline { 2 - 7 } & $\delta^{2} \mathrm{~s}$ & $\mathrm{~V} \%^{*}$ & $\delta^{2} \mathrm{D}: \mathrm{s}$ & $\mathrm{V} \%^{*}$ & $\delta^{2} \mathrm{e}$ & $\mathrm{V}^{*}$ \\
\hline EASM & 0.26 & 3.73 & 2.85 & 40.88 & 3.86 & 55.39 \\
\hline RBC & 0.21 & 3.64 & 1.60 & 27.73 & 3.96 & 68.63 \\
\hline
\end{tabular}

These results were in agreement with those obtained by El-Fiky (2005), AboulHassan (2000 a) and Aboul-Seoud et al. (2009) when they selected Japanese quail for increased BW6 and BW4, and ElBourhamy (2004) when he selected Japanese quail for increased feed consumption.

\subsection{Selection differential}

Selection differential calculated as expected and actual as well as the ratio between the actual and expected selection differentials (Actual/Expected) are presented in Table (5) for EASM line. However, no significant differences were found between the actual and expected selection differentials from generation zero to generation four. This means that the distribution of EASM confirm with the properties of a normal distribution closely enough to allow fairly accurate prediction. The ratio of actual to expected selection differentials (Table 5) was greater than unity, which suggests that natural selection may had a positive effect on selection for EASM. The same trend was noticed by Aboul-Hassan (2001 b) and El-Fiky (2005) when they selected Japanese quail for high $\mathrm{BW}_{6}$ and Abu-Mosallam (2014) when he selected Japanese quail for increased feed and water consumption among 3generations of selection. Moreover, Marks and Lepore (1968) among two lines of Japanese quail selected for body weight at 4 weeks of age for six generations. Cumulative (actual and expected) selection differentials are presented in Table (6). The values for cumulative selection differentials (Actual and Expected) were 2.51 and $2.02 \mathrm{~d}$ at generation zero among the (EASM) line decreased to 2.11 and $1.96 \mathrm{~d}$ at generation four. The cumulative actual 
selection differential takes into account through fertility of selected phenotypes the effects of natural selection expressed (Falconer, 1954).

Table (5): Actual and expected selection differentials and the ratio of actual to expected selection differentials for early age at sexual maturity.

\begin{tabular}{lccc}
\hline \multirow{2}{*}{ Generation } & \multicolumn{3}{c}{ Selection differentials } \\
\cline { 2 - 4 } & Actual & Expected & Actual / Expected \\
\hline 0 & $2.52 \pm 0.18$ & $2.43 \pm 0.16$ & 1.04 \\
\hline 1 & $2.61 \pm 0.25$ & $2.16 \pm 0.18$ & 1.21 \\
\hline 2 & $2.97 \pm 0.16$ & $2.62 \pm 0.20$ & 1.13 \\
\hline 3 & $2.31 \pm 0.05$ & $2.22 \pm 0.12$ & 1.04 \\
\hline Average & $2.18 \pm 0.13$ & $2.01 \pm 0.12$ & 1.08 \\
\hline
\end{tabular}

Table (6): Cumulative (actual and expected) selection differentials for early age at sexual maturity.

\begin{tabular}{lcc}
\hline \multirow{2}{*}{ Generation } & \multicolumn{2}{c}{ Selection differentials } \\
\cline { 2 - 3 } & Cumulative (Actual) & Cumulative (Expected) \\
\hline 0 & 2.51 & 2.02 \\
\hline 1 & 2.04 & 1.76 \\
\hline 2 & 1.85 & 1.92 \\
\hline 4 & 1.90 & 2.11 \\
\hline Average & 2.11 & 1.96 \\
\hline
\end{tabular}

\subsection{Selection response}

The actual and cumulative selection responses are presented in Table (7). The actual response to selection in the line EASM decreased or/ increased from generation to another through the four generations of selection. The estimated response to selection after the first generation of selection was 1.42 day, then it decreased and increased gradually as the selection continued to $1.28,1.32$ and 1.82day after the second, the third and the fourth generation of selection among EASM line. This regularity of the selection response had been observed in many selection experiments reported in the literature. The cumulative response to selection in the EASM line was 5.84 day after the fourth generation of selection. However, El-Fiky (2005) reported that the actual response to selection for $\mathrm{HBW}_{6}$ was $2.58 \mathrm{~g}$ after the first generation of selection and fluctuated to be $1.82 \mathrm{~g}$ after the fourth generation of selection. Moreover, Aboul-Seoud et al. (2009) reported that the actual response to selection in the line $\left(\mathrm{HBW}_{4}\right)$ was decreased from generation to another through the three generations of selection. Abu-Mosallam (2014) when he selected Japanese quail for increased feed 
consumption among three generations of selection found that the actual response to selection in the line $\left(\mathrm{HWC}_{4-6}\right)$ was decreased from generation to another through the three generations of selection. On the other hand, Falconer (1954) have shown that the irregularity in response to selection might have been due to many causes of genetically or environmental nature. Differences in natural selection differential, fertility and/or genetic-environment interaction on BW might cause such irregularity in selection response especially in such small numbers of generations as it was the case in the present study.

Table (7): Actual and cumulative selection responses for early age at sexual maturity.

\begin{tabular}{lcc}
\hline \multirow{2}{*}{ Generation } & \multicolumn{3}{c}{ Selection responses } \\
\cline { 2 - 3 } & Actual & Expected \\
\hline $0-1$ & $1.42 \pm 0.85$ & 1.42 \\
\hline $1-2$ & $1.28 \pm 0.54$ & 2.70 \\
\hline $2-3$ & $1.32 \pm 0.47$ & 4.02 \\
\hline $3-4$ & $1.82 \pm 0.67$ & 5.84 \\
\hline Average & $1.46 \pm 0.92$ & ----- \\
\hline
\end{tabular}

\subsection{Heritability estimates}

\subsubsection{Components of variance}

Heritability estimates for early age at sexual maturity calculated from components of variance i.e. sire (paternal half-sibs), dam within sire (maternal halfsibs) and sire plus dam (full-sibs) among the EASM line are presented in Table (8). However, the dam component is expected to be larger in magnitude by the variances due to the dominance deviations and maternal effects. Heritabilities computed from the sire component $\left(\mathrm{h}_{\mathrm{S}}^{2}\right)$ ranged between 0.18 and 0.23 among the four generations of selection and that computed from the dam components $\left(\mathrm{h}_{\mathrm{D}}^{2}\right)$ are generally higher than those computed from the sire components, it ranged between 0.29 and 0.39 . This may be due to the large dam variance components obtained and the non-genetic effects, primarily dominance and maternal, normally result in the $\mathrm{h}^{2}$ D estimates being considerably larger than $\mathrm{h}_{\mathrm{S}}^{2}$ estimates. While, heritabilities computed from fullsib components $\left(\mathrm{h}_{\mathrm{S}+\mathrm{D}}^{2}\right)$ ranged between moderate and high in magnitude (0.200.28 ). The results are in agreement with the corresponding values reported by Debes (2004), Meky (2007), Abou Khadiga et al. (2016) and Kaye et al. (2016).

\subsubsection{Realized heritability}

The realized heritability estimated for early age at sexual maturity. As the ratio between response to selection and selection differential (R/S) calculated from the EASM line presented per generation in Table (8). The estimates of the realized heritability for early sexual maturity increased from 0.56 at the first generation to 0.79 at the fourth generation. 
Table (8): Heritability estimates computed from sire, dam, sire plus dam components of variance and realized heritability for early age at sexual maturity.

\begin{tabular}{lcccc}
\hline Heritability / Generation & $\begin{array}{c}\text { Sires } \\
\mathrm{h}_{\mathrm{S}}^{2} \pm \mathrm{S} . \mathrm{E}\end{array}$ & $\begin{array}{c}\text { Dams: Sires } \\
\mathrm{h}_{\mathrm{D}: \mathrm{S}}^{2} \pm \mathrm{S} . \mathrm{E}\end{array}$ & $\begin{array}{c}\text { Full-sibs } \\
\mathrm{h}_{\mathrm{S}+\mathrm{D}}^{2} \pm \mathrm{S} . \mathrm{E}\end{array}$ & $\begin{array}{c}\text { Realized } \\
\mathrm{h}^{2} \pm \mathrm{S} . \mathrm{E}\end{array}$ \\
\hline 1 & $0.23 \pm 0.43$ & $0.30 \pm 0.58$ & $0.27 \pm 0.45$ & $0.56 \pm 0.22$ \\
\hline 2 & $0.20 \pm 0.38$ & $0.35 \pm 0.75$ & $0.23 \pm 0.66$ & $0.49 \pm 0.31$ \\
\hline 4 & $0.21 \pm 0.52$ & $0.29 \pm 0.65$ & $0.20 \pm 0.58$ & $0.44 \pm 0.26$ \\
\hline
\end{tabular}

\subsection{Correlated responses}

Selection for EASM had consequences for some other traits. The weights and/or the weight gains recorded at different ages and growth periods, egg production, reproductive traits and the carcass traits may be changed. The actual means of the correlated traits associated with selection for EASM are presented in Tables (9 to 11).

\subsubsection{Correlated responses}

Body weights for the EASM line $\left(\mathrm{BW}_{0}\right.$, $\mathrm{BW}_{2}, \quad \mathrm{BW}_{4}$ and $\left.\mathrm{BW}_{6}\right)$ increased significantly $(\mathrm{P} \leq 0.05)$ from 9.95, 40.58, 98.84 and $170.47 \mathrm{~g}$ in the first generation to $10.47,47.01,101.87$ and $181.42 \mathrm{~g}$ after four generations of selection (Table 9). However, body weight gain traits among the EASM line Average daily gain from 0-2 weeks of age, Average daily gain from 2-4 weeks of age, Average daily gain from 4-6 weeks of age and Average daily gain from $0-6$ weeks of age $\left(\mathrm{ADG}_{0-}\right.$ 2, $\mathrm{ADG}_{2-4}, \mathrm{ADG}_{4-6}$ and $\left.\mathrm{ADG}_{0-6}\right)$ increased significantly $(\mathrm{P} \leq 0.05)$ from $2.43,5.40$, 1.52 and $3.62 \mathrm{~g} /$ day in the first generation to $2.92,5.98,1.90$ and $4.04 \mathrm{~g} /$ day after four generations of selection. Similar results were reported by Silva et al. (2013), Abou-Khadiga et al. (2014), Mahmoud et al. (2014), Saima et al. (2014), Aboul- Hassan et al. (2016) and El-Fiky et al. (2016).

Table (9): Actual means and standard deviations (S.D) for growth traits studied in both sexes for lines and generations of selection when selection was applied for early age at sexual maturity.

\begin{tabular}{lcccccccc}
\hline \multirow{2}{*}{ Line Gen Trait } & \multicolumn{4}{c}{ Early age at sexual maturity } & \multicolumn{4}{c}{ Random bred control line } \\
\cline { 2 - 9 } & 1 & 2 & 3 & 4 & 1 & 2 & 3 \\
\hline $\mathrm{BW}_{0}$ & $9.95 \pm 0.60$ & $10.57 \pm 0.62$ & $10.75 \pm 0.43$ & $10.47 \pm 0.62$ & $9.85 \pm 0.82$ & $9.64 \pm 0.74639$ & $9.59 \pm 0.85$ & $10.00 \pm 0.62$ \\
\hline $\mathrm{BW}_{2}$ & $40.58 \pm 4.22$ & $42.05 \pm 4.24$ & $47.01 \pm 5.32$ & $42.85 \pm 4.26$ & $40.25 \pm 4.72$ & $41.80 \pm 4.24$ & $40.66 \pm 4.86$ & $42.05 \pm 0.29$ \\
\hline $\mathrm{BW}_{4}$ & $98.84 \pm 14.56$ & $101.87 \pm 15.40$ & $101.45 \pm 17.62$ & $100.87 \pm 15.48$ & $96.52 \pm 12.55$ & $97.22 \pm 14.57$ & $98.58 \pm 16.17$ & $87 \pm 15.40$ \\
\hline $\mathrm{BW}_{6}$ & $170.47 \pm 16.41$ & $178.02 \pm 17.18$ & $182.42 \pm 16.15$ & $179.02 \pm 17.58$ & $165.78 \pm 17.20$ & $162.54 \pm 16.10$ & $164.05 \pm 11.85$ & $168.02 \pm 14.18$ \\
\hline $\mathrm{ADG}_{0-2}$ & $2.43 \pm 0.34$ & $2.82 \pm 0.33$ & $2.89 \pm 0.44$ & $2.92 \pm 0.37$ & $2.44 \pm 0.40$ & $2.32 \pm 0.589$ & $2.42 \pm 0.67$ & $2.52 \pm 0.30$ \\
\hline $\mathrm{ADG}_{2-4}$ & $5.40 \pm 0.66$ & $5.88 \pm 0.62$ & $5.90 \pm 0.62$ & $5.98 \pm 0.69$ & $5.65 \pm 0.45$ & $5.35 \pm 0.61$ & $5.48 \pm 0.40$ & $5.58 \pm 0.90$ \\
\hline $\mathrm{ADG}_{4-6}$ & $1.52 \pm 0.31$ & $1.70 \pm 0.52$ & $1.81 \pm 0.61$ & $1.90 \pm 0.57$ & $1.55 \pm 0.30$ & $1.52 \pm 0.45$ & $1.52 \pm 0.60$ & $1.60 \pm 0.92$ \\
\hline $\mathrm{ADG}_{0-6}$ & $3.62 \pm 0.50$ & $3.84 \pm 0.93$ & 3.90 .42 & $4.04 \pm 0.63$ & $3.74 \pm 0.48$ & $3.60 \pm 0.30$ & $3.65 \pm 0.38$ & $3.71 \pm 0.93$ \\
\hline
\end{tabular}


Table (10): Actual means and standard deviations for egg production and reproductive traits studied in females for lines and generations of selection when selection was applied for early age at sexual maturity.

\begin{tabular}{lcccccccc}
\hline \multirow{2}{*}{ Line Gen Trait } & \multicolumn{9}{c}{ Early age at sexual maturity } & \multicolumn{5}{c}{ Random bred control line } \\
\cline { 2 - 11 } EW & 1 & 2 & 3 & 4 & 1 & 2 & 3 \\
\hline BWSM & $10.64 \pm 18.95$ & $10.94 \pm 19.52$ & $11.46 \pm 10.62$ & $10.74 \pm 18.90$ & $10.45 \pm 10.60$ & $10.85 \pm 10.28$ & $10.70 \pm 11.25$ & $10.55 \pm 10.28$ \\
\hline TEN10 & $56.32 \pm 18.95$ & $143.02 \pm 28.05$ & $146.35 \pm 22.16$ & $139.32 \pm 18.35$ & $138.72 \pm 19.65$ & $137.72 \pm 18.00$ & $139.12 \pm 16.95$ & $137.43 \pm 18.06$ \\
\hline TEW10 & $454.25 \pm 14.23$ & $460.54 \pm 16.44$ & $463.25 \pm 13.65$ & $467.25 \pm 14.26$ & $462.54 \pm 15.60$ & $466.18 \pm 15.03$ & $462.64 \pm 14.18$ & $466.87 \pm 15.13$ \\
\hline DEM & $9.44 \pm 6.29$ & $9.25 \pm 6.48$ & $9.10 \pm 6.58$ & $9.64 \pm 6.69$ & $9.37 \pm 4.78$ & $9.77 \pm 5.66$ & $9.70 \pm 5.02$ & $9.54 \pm 5.66$ \\
\hline FR\% & 80.58 & 79.60 & 78.60 & 80.90 & 82.25 & 84.51 & 83.39 & 84.51 \\
\hline HA\% & 70.42 & 68.09 & 66.61 & 70.92 & 73.95 & 75.02 & 74.28 & 75.02 \\
\hline EEM\% & 5.63 & 6.64 & 6.93 & 5.93 & 5.71 & 6.13 & 5.43 & 6.10 \\
\hline LEM\% & 17.00 & 16.98 & 16.34 & 16.34 & 15.88 & 15.60 & 15.41 & 15.62 \\
\hline TEM\% & 22.27 & 23.62 & 23.93 & 21.97 & 21.59 & 21.73 & 20.84 & 21.72 \\
\hline
\end{tabular}

\subsubsection{Egg production and reproductive traits}

Egg weight (EW) was decreased significantly $(\mathrm{P} \leq 0.05)$ from $10.64 \mathrm{~g}$ in the first generation to $10.74 \mathrm{~g}$ after four generations of selection (Table 10). BWSM was insignificantly increased $(\mathrm{P} \leq 0.05)$ from $136.32 \mathrm{~g}$ in the first generation to $139.32 \mathrm{~g}$ after four generations of selection (Table 10). While $\mathrm{TEN}_{10}$, insignificantly increased $(\mathrm{P} \leq 0.05)$ from $55.25 \mathrm{egg}$ in the first generation to $54.25 \mathrm{egg}$ after four generations of selection. While $\mathrm{TEW}_{10}$ and DEM were significantly increased $(\mathrm{P} \leq 0.05)$ from $454.25 \mathrm{~g}$ and $9.41 \mathrm{~g} /$ day in the first generation to $467.25 \mathrm{~g}$ and $9.64 \mathrm{~g} /$ day after four generations of selection (Table 10). However, reproductive traits: Fertility percentage (FR \%) was significantly increased $(\mathrm{P} \leq 0.05)$ from $80.58 \%$ in the first generation to $80.90 \%$ after four generations of selection and hatchability percentage (HA \%) were significantly increased $(\mathrm{P} \leq 0.05)$ from $70.42 \%$ in the first generation to $70.92 \%$ after four generations of selection (Table 10).
While, early embryonic mortality (EEM $\%)$ increased significantly $(\mathrm{P} \leq 0.05)$ from $5.63 \%$ in the first generation to $5.93 \%$ after four generations of selection, and lately embryonic mortality (LEM \%), and total embryonic mortality. Total embryonic mortality (TEM \%) were decreased significantly $(\mathrm{P} \leq 0.05)$ from 17.00 and $22.27 \%$ in the first generation to 16.34 and $21.97 \%$ after four generations of selection. The same trend was noticed by Ozdemir and Poyraz (2000), Aboul-Seoud et al. (2009), Abo Samaha et al. (2010), Okenyi et al. (2013), Abu-Mosallam (2014), Dauda et al. (2014) and Faruque Shakila et al. (2016). On the contrary, the corresponding values for the control line among egg production and reproductive traits studied were fluctuated from generation to another with no significant trend (Table 10).

\subsubsection{Carcass traits}

Meat dressing and giblets (\%) were increased significantly $(\mathrm{P} \leq 0.05)$ from $42.33,62.04$ and $14.27 \%$ in the first 
generation to $43.76,63.99$ and $14.99 \%$ significantly $(\mathrm{P} \leq 0.05)$ from $9.05 \%$ in the after four generations of selection. While, first generation to $8.53 \%$ after four bone $(\%)$ traits were decreased generations of selection (Table 11).

Table (11): Actual means and standard deviations for carcass traits studied in both sexes for lines and generations of selection when selection was applied for early age at sexual maturity.

\begin{tabular}{lcccccccc}
\hline \multirow{2}{*}{ Line Gen Trait } & \multicolumn{3}{c}{ Early age at sexual maturity } & \multicolumn{4}{c}{ Random bred control line } \\
\cline { 2 - 9 } & 1 & 2 & 3 & 4 & 1 & 2 & 3 \\
\hline Meat \% & 42.33 & 48.44 & 46.05 & 43.76 & 44.00 & 45.38 & 45.18 & 44.76 \\
\hline Giblets \% & 14.27 & 14.67 & 14.90 & 14.99 & 14.89 & 14.48 & 14.39 & 15.04 \\
\hline Bone \% & 9.05 & 8.96 & 8.70 & 8.53 & 8.24 & 8.57 & 8.02 & 8.65 \\
\hline Dressing \% & 62.04 & 62.91 & 63.44 & 63.99 & 61.69 & 60.98 & 61.39 & 60.89 \\
\hline
\end{tabular}

The same trend was noticed by Mohammed (1990), Abdel-Tawab (2006), Abu-Mosallam (2014), Aboul-Hassan et al. (2016) and El-Fiky et al. (2016). On the contrary, the corresponding values for the control line among carcass traits studied were fluctuated from generation to another with no significant trend (Table $11)$.

\section{References}

Abdel-Tawab, S. K. (2006), The effect of selection for egg weight on some productive traits in Japanese quail, M.Sc. Thesis, Faculty of Agriculture, Al-Azhar University, Cairo, Egypt.

Abo Samaha, I. M. M., Sharaf, M. and Hemeda, S. A. (2010), "Phenotypic and genetic estimates of some productive and reproductive traits in Japanese quails", Egyptian Poultry Science, Vol. 30 No. 3, pp. 875-892. Abou-Khadiga, G., Mahmoud, B. Y. F. and El-Full, E. A. (2016), "Genetic evaluation of early egg production and maturation traits using two different approaches in Japanese quail", Poultry science, Vol. 95 No. 4, pp. 774-779.

Aboul-Hassan, M. A. (2000), "Comparative study of growth traits in two strains of Japanese quail", Fayoum Journal of Agriculture Research \& Development, Vol. 14, pp. 189-197.

Aboul-Hassan, M. A. (2001a), "Crossbreeding effects on some growth and egg production traits among two strains of Japanese quail", Al-Azhar Journal of Agriculture Research, Vol. 34, pp. 41-57.

Aboul-Hassan, M. A. (2001b)," Selection for high egg production in Japanese quail-direct and correlated responses", Al-Azhar Journal of Agriculture Research, Vol. 34, pp. 25-40.

Aboul-Hassan, M. A., El-Fiky, F. A., 
Aboul-Seoud, D. I. and Ramzy, A. A. (2016), "Direct and Correlated Responses from long-term selection for water consumption in Japanese quail", Middle East Journal of Applied Science, Vol. 7, pp. 126134.

Aboul-Seoud, D. I., Kadry, A. E. H., Mabrouk, M. M. S., Aboul-Hassan, M. A. and Mohammed, F. A. (2009), "Divergent selection for egg production in Japanese quail - direct responses", Al-Azhar Journal of Agriculture Research, Vol. 6, pp. 121-136.

Abu-Mosallam, M. F. (2014), Selection for feed and water consumption and its correlated responses with some productive and reproductive traits in Japanese quail, Ph.D. Thesis, Faculty of Agriculture, Al-Azhar University, Cairo, Egypt.

Al-Tikriti, S. S. A. (2018), "The effect of the selection for the age trait at sexual maturity of two generations in the productive performance of black Japanese quail bird", Journal of Advanced Veterinary and Animal Research, Vol. 6 No. 12, pp. 548555.

Dauda, G., Momoh, O. M., Dim, N. I. and Ogah, D. M. (2014), "Growth, production and reproductive performance of Japanese quails (Coturnix japonica) in humid environment", Egyptian Poultry Science Journal, Vol. 34 No. 2, pp. 381-395.
Debes, A. H. (2004), Selection indices for improving economic traits in Japanese quail, Ph.D. Thesis, Faculty of Agriculture, Alexandria University, Alexandria, Egypt.

El-Bourhamy, S. F. (2004), The effect of selection for feed efficiency on body weight and productive traits in Japanese quail, M.Sc. Thesis, Faculty of Agriculture, Al-Azhar University, Cairo, Egypt.

El-Fiky, F. A. (2005), "Selection for high body weight at sex weeks of age in Japanese quail-direct and correlated responses", Al-Azhar Journal of Agriculture Research, Vol. 42, pp. 15-27.

El-Fiky, F. A, Aboul-Hassan, M. A., Aboul-Seoud, D. I. and Ramzy, A. A. (2016), "Direct and Correlated Responses from long-term selection for feed consumption in Japanese quail", Al-Azhar Journal of Agriculture Research, Vol. 26, pp. 89-105.

Falconer, D. S. (1954), Asymmetrical responses in selection experiments, Symposium on Genetics of Population Structure, pp. 16-41.

Faruque, S., Ali, M. Y., Bhuyian, A. F. H., Joy, Z. F. and Rabbani, M. A. G. (2016), "Productive and reproductive performances and expected response to selection of second generation of quail varieties", Asian Journal of Medical and Biological Research, Vol. 2 No. 
4, pp. 631-634.

Harvey, W. R. (1987), User's guide for LSML 86, mixed mode least-squares and maximum likelihood computer program Mimeo, Ohio State University, United States of America.

Henderson, C. R. (1953), "Estimation of variance and covariance components", Biometrics, Vol. 9 No. 2, pp. 226-252.

Inal, S., Dere, S. and Kirikci, T. C. (1996), "Japon bildirein larinda (Coturnix japonica) Canli agirligi gore yaplan selekslyonum verimi, yamurta verimi, yamurta Agirligi fertilite. Kulucka Randman ve yasama gtictine etkileri", Journal of the Turkish Veterinary Medical Society, Vol. 12 No. 2, pp. 13-22.

Kayang, B. B., Vignal, A., InoueMurayama, M., Miwa, M., Monvoisin, J. L., Ito, S. and Minvielle, F. (2004), "A first generation microsatellite linkage map of the Japanese quail", Animal Genetics, Vol. 35, pp. 195-200.

Kaye, J., Akpa, G. N., Alphonsus, C., Kabir, M., Zahraddeen, D. and Shehu, D. M. (2016), " Responsed to Genetic improvement and heritability of egg production and egg quality traits in Japanese quail (Coturnix japonica)", American Scientific Research Journal for Engineering, Technology and Sciences, Vol. 16 No. 1, pp. 277-
292.

Mahmoud, B. Y. F., Abou-Khadiga, G. and El-Full, E. A. (2014), "Direct and correlated responses to shortterm index selection for some economic traits of Japanese quail", Egyptian Poultry Science, Vol. 34, pp. 761-778.

Marks, H. L. (1971), "Selection for four week body weight in Japanese quail under two nutritional environments", Poultry Science, Vol. 50, pp. 931937.

Marks, H. L. and Lepore, P. D. (1968), "Growth rate inheritance in Japanese quail: 2- Early response to selection under different nutritional environments", Poultry Science, Vol. 47, pp. 1540-1546.

Meky, M. A. M. (2007), "Effect of age at sexual maturity on some production traits in Japanese quail, M.Sc. Thesis, Faculty of Agriculture, Alexandria University, Damanhour, Egypt.

Nestor, K. E., Bacon, W. L. and Lambio, A. L. (1983), "Divergent selection for egg production in Coturnix japonica", Poultry Science, Vol. 62, pp. $1548-1552$.

Okenyi, N., Ndofor-Foleng, H. M., Ogbu, C. C. and Agu, C. I. (2013), "Genetic parameters and consequences of selection for shortterm egg production traits in Japanese quail in a tropical 
environment", African Journal of Biotechnology, Vol. 12 No. 12, pp. 1357-1362.

Ozdemir, E. and Poyraz, Ö. (2000), "Effect of inbreeding on some production traits of quail", Lalahan Hayvancılık Araștırma Enstitüsü Dergisi, Vol. 40 No. 1, pp. 48-64.

Saima, M. A., Shad, T. N., Pasha, M., Akram, Y., Ditta, A. and Khan, M. Z. U. (2014), "Effect of microbial phytase supplementation on growth performance of Japanese quails", Journal Animal and Plant Science, Vol. 24, pp. 19-23.
Varkoohi, S. and Kaviani, K. (2014), "Genetic improvement for body weight of Japanese quail", Annual Research \& Review in Biology, Vol. 4, pp. 347-353.

Jensen, T., Pernasetti, F. M. and Durrant, B. (2003), "Conditions for rapid sex determination in 47 avian species by PCR of genomic DNA from blood, shell membrane blood vessels, and feathers", Zoo Biology, Vol. 22 No. 6, pp. 561-571. 